\title{
Moisture origin and characteristics of the isotopic signature of rainfall in a Mediterranean mountain catchment (Vallcebre, eastern Pyrenees)
}

\author{
Enric Casellas ${ }^{\mathrm{a}, *}$, Jérôme Latron ${ }^{\mathrm{b}}$, Carles Cayuela ${ }^{\mathrm{b}}$, Joan Bech ${ }^{\mathrm{a}}$, Mireia \\ Udina $^{\mathrm{a}}$, Yolanda Sola ${ }^{\mathrm{a}}$, Keun-Ok Lee ${ }^{\mathrm{c}}$, Pilar Llorens ${ }^{\mathrm{b}}$ \\ ${ }^{a}$ Department of Applied Physics - Meteorology, University of Barcelona, Barcelona. \\ ${ }^{b}$ Surface Hydrology and Erosion Group, Institute of Environmental Assessment and Water \\ Research (IDAEA), CSIC, Barcelona, Spain. \\ ${ }^{c}$ Laboratoire d'Aérologie, Université de Toulouse, CNRS, UPS, Toulouse, France.
}

\begin{abstract}
This study investigates moisture origin, characteristics and intra-event scale variability of the isotopic signature of rainfall in a Mediterranean mountain area, based on data from the Vallcebre Research Catchments, NE Spain. Weekly data and samples were used to analyse the general dynamics of the isotopic composition of precipitation and its relationship with meteorological variables at the sampling site. Then, based on the data and samples available at the intraevent scale, the variability of the isotopic signature during rainfall events was characterised and an explanation of what caused the observed variability was attempted. Results at the weekly time scale show that the maximum relative deviation of the heavy isotopic content with respect to Standard Mean Ocean Water $\left(\delta^{18} O\right)$ of the precipitation signature occurred during summer months and, in contrast, the minimum during winter months. The intra-annual trend of rainfall $\delta^{18} O$ roughly followed the mean monthly air temperature. Using intraevent information, three main types of $\delta^{18} O$ isotopic trends were found during rainfall events: most of the events had a $\mathrm{V}$-shaped isotopic trend, followed by L-shaped and constant trend events. Changes in moisture sources - diagnosed using a Lagrangian approach and a previously existing contribution algorithm-
\end{abstract}

\footnotetext{
*Enric Casellas

Email address: enric.casellas@meteo.ub.edu (Enric Casellas)
}

Preprint submitted to Journal of Hydrology

May 14, 2019 
were one of the causes of the isotopic variability and changes at the intra-event scale, but these may also have been influenced by sub-cloud processes that modified the isotopic signature. Moisture sources for analysed events showed the main influence of the Mediterranean area, but also an important influence of the Atlantic Basin.

Keywords: Precipitation, stable isotopes, backward trajectories, moisture source regions, intra-event scale analysis, Mediterranean area

\section{Introduction}

The stable isotopes of water, oxygen-18 and deuterium, play an important role in the study of the global hydrologic cycle (Gat, 1996). Natural waters, mainly the oceans, have a relatively uniform isotopic composition (Dansgaard, 5 1964, LeGrande \& Schmidt, 2006), whereas meteoric waters are not in partitioning equilibrium. The reason is isotopic fractionation, which can be differentiated into two types: equilibrium and non-equilibrium fractionations. The former implies that the ratios of different isotopes in each compound are constant for a particular temperature (Kendall \& McDonnell, 1998). An example would be the condensation of water vapour to form rain clouds, where the molecules with heavier isotopes condense more easily than those with light isotopes. In this case, the liquid phase of water is enriched with heavy isotopes, whereas light isotopes are left in the vapour phase. The non-equilibrium fractionations, also known as kinetic fractionations, rely on the ratios of the masses of the isotopes and their vibrational energies (Craig, 1961). Bonds of molecules with light isotopes are easily broken and react faster than molecules with heavy isotopes. An example of kinetic fractionation is raindrops evaporation, which implies the isotopic exchange between precipitation and the surrounding moisture in the sub-cloud layer during its path to the surface (Dansgaard, 1964).

Isotopic composition of precipitation varies greatly and depends on many factors, among which are the origin of the air masses, the rain-out history, evaporation and condensation conditions when the precipitation forms and atmospheric 
transport (Dansgaard, 1964, Gat \& Gonfiantini, 1981, Rozanski et al., 1992). Dansgaard (1964) also found a seasonal variation and latitude, altitude and continental effects on isotopic composition of precipitation, which are related to rain-out history and temperature. Finally, several studies (e.g. Dansgaard, 1964, Rozanski et al., 1992; Araguás-Araguás et al., 2000, Yu et al., 2016, Ren et al., 2017) show a relationship between stable isotopes and local meteorological variables such as air temperature, relative humidity or rainfall amount. The variability of the isotopic composition of precipitation is not only present in the source area or during atmospheric transport, but also at the intra-event scale. This has led to the study of single rain events in order to analyse the variations in the isotopic content of precipitation and relate these to atmospheric processes (Rindsberger et al., 1990; Good et al., 2014). Three main isotopic trends have 35 been identified in different rainfall events: L-shaped, V-shaped and constant trends (e.g. Miyake, 1968; Celle-Jeanton et al., 2001, 2004, Muller et al., 2015). The trend of the isotopic composition of precipitation at the event scale depends on rainfall intensity, the altitude where rain forms, whether it is convective or stratiform rain and if it is caused by a cold or warm front, among other considerations. Apart from the analysis of isotopic trends, the origin of air masses and the identification of moisture sources have also been the subjects of many studies. Celle-Jeanton et al. (2001) found that precipitation from Mediterranean sources was more enriched in heavy isotopes than that from Atlantic sources; Liotta et al. (2008) related the isotopic composition of rainfall events in Sicily

45 to evaporation from the different areas of the Mediterranean Sea around the island.

Many other studies used a trajectory analysis to determine the moisture sources. Guan et al. (2013) used the HYSPLIT (Hybrid Single Particle Lagrangian Integrated Trajectory Model) model to analyse deuterium excess (dexcess) variations in relation with atmospheric sources in Australia; Tyler et al. (2016) worked with the HYSPLIT model to study moisture sources at daily time scale in the British Isles; Guo et al. (2017) also used the aforementioned model to derive the moisture transport path of individual events on the Tibetan Plateau; 
Lekshmy et al. (2018) analysed the moisture source during monsoon in India;

${ }_{55}$ Pfahl \& Wernli (2008), Winschall et al. (2014) and Krklec et al. (2018) used a moisture diagnostic algorithm proposed by Sodemann et al. (2008) to determine quantitatively, rather than only qualitatively, the moisture sources in the Eastern Mediterranean, the North-Western Mediterranean and Central Europe, respectively. In addition, Pfahl \& Wernli (2008) used a Lagrangian approach (RHSST) of the moisture sources. This information opened up the possibility of inferring whether intra-event variability is related to a change in the moisture source or to other meteorological processes. The quantitative approach followed by Pfahl \& Wernli (2008) established a relationship between the moisture source's meteorological variables, which include sea surface temperature and two-meter relative humidity, and d-excess. The relevance of using d-excess is that it is a parameter correlated with the physical conditions of the moisture sources (Froehlich et al., 2002; Guan et al., 2013, Pfahl \& Sodemann, 2014). For instance, high deuterium excess values indicate low relative humidity at the moisture sources. Consequently, a change in d-excess value may be related to a change in the moisture source. Hence, the isotope signature of precipitation at a specific measurement site represents the total imprint of all equilibrium and non-equilibrium fractionation processes that occurred during its transport. In the last 30 years, the Vallcebre Research Catchments have concentrated on many studies concerned with understanding the hydrological functioning of Mediterranean mountain catchments (Llorens et al. 2018). In some recent studies that used stable isotopes of water, some significant variability in isotopic composition of precipitation at the event-scale was observed. This variability has been taken into account in the study of hydrological processes using stable isotopes so (Cayuela et al., 2018), but the dynamics and the reasons for this variability remain unclear.

This study focuses on what is happening before the precipitation reaches the ground and, in particular, addresses the question of which are the factors behind the variability in isotopic composition in precipitation events. For this purpose, 
the isotopic composition of precipitation sampled in the Vallcebre Research

Catchments was analysed to obtain a Local Meteoric Water Line and to test the relationship of $\delta^{18} O$ with local air temperature and rain amount. Then, based on intra-event scale data, the different trends followed by the isotopic composition of precipitation were analysed. Different processes may determine

90 the isotopic variability and its values, such as rainfall intensity, conditions below the cloud, altitude at which rain is produced, the weather system involved and changes in air masses (Muller et al. 2015). Altogether were analysed to establish its importance in governing intra-event isotopic variability and mean isotopic event values. To account for changes in air masses, a backward trajectory analysis based on the methodology proposed by Sodemann et al. (2008) was done with the HYSPLIT model to quantify the origin of moisture. This approach enabled us to document the moisture source of selected events and relate it to their d-excess values, so providing a deeper understanding of possible processes influencing isotopic variability of precipitation.

\section{Methodology}

\subsection{Study site}

The Vallcebre Research Catchments are located at the headwaters of the Llobregat river on the southern margin of the Pyrenees, NE Spain $\left(42^{\circ} 12^{\prime} \mathrm{N}\right.$, $1^{\circ} 49^{\prime} \mathrm{E}$ ) with altitudes between 1,100 and 1,700 m above sea level (a.s.l.) (Gallart et al. 2005). There are different sub-catchments: Cal Parisa $\left(0.32 \mathrm{~km}^{2}\right)$ and Cal Rodó $\left(4.17 \mathrm{~km}^{2}\right)$, which in turn has two sub-catchments, Can Vila $\left(0.56 \mathrm{~km}^{2}\right)$ and Ca l'Isard $\left(1.32 \mathrm{~km}^{2}\right)$. This area has been used since 1989 for the study and modelling of hydrological processes, with the aim of providing new information to evaluate the effects of global change on water resources in Mediterranean catchments (Latron et al., 2014). A complete overview of the results obtained in the Vallcebre Research Catchments can be found in Llorens et al. (2018).

The site climate is defined as Mediterranean humid with a mean annual temperature of $9.1^{\circ} \mathrm{C}$ at $1,260 \mathrm{~m}$ a.s.l. It has a mean of 90 rainy days per year 
with a mean annual rainfall of $880 \pm 200 \mathrm{~mm}$ (Llorens et al., 2018).

\subsection{Data acquisition and analyses}

The rainfall isotopic data used in this study were sampled in two periods between 2011 and 2016, the first from May 2011 to July 2013 and the second from May 2015 to December 2016. This information was complemented with rainfall and meteorological data measured at an automatic meteorological station located in the upper part of the Can Vila sub-catchment. Rainfall was measured with a tipping-bucket rain gauge located $1 \mathrm{~m}$ above the ground (Casellas cell, UK) and air temperature and relative humidity with respective probes (Vaisala, Finland). All data were measured every 10 seconds and recorded at 5-min intervals by a datalogger (DT500 Datataker, Australia). Two types of rainwater samplers, located next to the rain gauge, were used. One was a bulk rainfall sampler consisting of a plastic funnel (130 mm diameter) connected to a polyethylene plastic bottle by looped tubing. The plastic bottle had $1 \mathrm{~L}$ capacity and was buried in the ground to prevent heating and evaporation. The other sampling device was a plastic funnel (340 mm diameter) connected to an automatic water sampler (24 polyethylene $500-\mathrm{mL}$ bottles, ISCO $3700 \mathrm{C}$, buried in the ground), which allowed for automatic sampling at $5 \mathrm{~mm}$-rainfall intervals. Using this sampling device, for $21 \%$ of the samples corresponding to intense rainfall (i.e. rainfall intensity higher than $5 \mathrm{~mm}$ in 5 minutes), a volume greater than $5 \mathrm{~mm}$ of rain may have been collected in a single ISCO bottle.

During the sampling periods, all samples were collected once a week, kept cold to avoid evaporation and sent to the laboratory. Rainfall samples were analysed for the relative deviation $\delta$ of the heavy isotopic content from a standard, $\delta^{18} O$ and $\delta D$, with a PICARRO L2120-i $\delta D / \delta^{18} O$ Isotopic Water Analyzer (Cavity Ring-Down Spectroscopy) by the scientific-technical services of Lleida University (Lleida, Spain). Results were expressed as parts per thousand (\%o) and calibrated to the Vienna Standard Mean Ocean Water (V-SMOW) (Craig, 1961). Precision was $<0.05 \%$ and $<0.3 \%$ for $\delta^{18} O$ and $\delta D$, respectively. 


\subsection{General and Local Meteoric Water Lines}

The covariance between $\delta^{18} O$ and $\delta D$ can be described by the relationship defined by Craig (1961) and known as the Global Meteoric Water Line (GMWL):

$$
\delta D=8 \cdot \delta^{18} O+10
$$

The intercept of 10 in Eq. (1) reflects that meteoric and oceanic waters are not in partitioning equilibrium. This value is defined as deuterium excess (d-excess), cancelling the covariation of deuterium and ${ }^{18} \mathrm{O}$ and resulting in a parameter less variable than both isotopes (Dansgaard, 1964). Although the GMWL is a useful baseline for comparing stable isotopic data, it may not reflect the characteristics or ratios of a local region. For this reason, a Local Meteoric Water Line (LMWL), with its own slope and intercept, is often developed to represent local meteoric conditions that may differ from those described in the GMWL (Kendall \& McDonnell, 1998).

\subsection{Rainfall events characterization}

Two parameters to characterize rainfall events were considered: type of precipitation and isotopic trend. The first one takes into account the synoptic meteorological situation, which was derived from analysis synoptic charts (Met Office, 2006), to determine whether precipitation was due to a cold (CF) or warm front (WF), a low-pressure system (L), or if it was a non-frontal convective shower $(\mathrm{S})$. The second one is based on a visual classification of the temporal evolution of the isotopic signature into one of the three commonly identified trends (e.g. Miyake, 1968; Celle-Jeanton et al., 2001, 2004): L-shaped, constant and V-shaped trend (Figures 1a, 1b and 1k, respectively). The L-shaped trend describes a steadily decrease of $\delta$ followed by a stationary trend. If the latter was followed by an increase of $\delta$, then the event would be labelled as V-shaped. Finally, if the isotopic signature remained mostly constant, it would be labelled as constant trend. For example, if the $\delta^{18} O$ evolution of an event followed first a depletion, then a constant trend and finally an enrichment, the trend event 170 would be labelled as V-shaped. 


\subsection{Moisture source identification and attribution}

In this study, the identification and attribution of moisture sources was based on the quantitative Lagrangian moisture source diagnosis proposed by Sodemann et al. (2008) and applied in several other studies (Sodemann et al., 2008.

175 et al. 2018). This methodology was based on the changes in specific humidity of an air parcel during its trajectory from a particular location to the study area. Two assumptions were made: (i) the integrity of the air parcels over several days and (ii) every change in specific humidity was related to evaporation tories of each selected rainfall event, the HYSPLIT model was used (Draxler \& Rolph, 2003, Stein et al. 2015). One-degree meteorological GDAS (Global Data Assimilation System) data were selected. Although a half-degree GDAS dataset was also available and provided a finer spatial resolution, it lacked the

avertical velocity that needed to be calculated from horizontal divergence. $\mathrm{Su}$ et al. (2015) found that backward trajectories calculated with half-degree GDAS datasets generate greater uncertainties than those with one-degree GDAS data. Thus, the coarser-resolution GDAS dataset was selected and downloaded from the portal available at the HYSPLIT interface. GDAS is used by the National Center for Environmental Predictions (NCEP) Global Forecast System (GFS) model to place observations into a gridded model space with a 3-hour temporal resolution. It is used by HYSPLIT, which finally delivers interpolated trajectory information with hourly resolution. The calculation process followed these three steps:

1. Definition of the starting location of the backward trajectories' calculation. In this study, the Vallcebre Research Catchments $\left(42^{\circ} 12^{\prime} \mathrm{N}, 1^{\circ} 49^{\prime} \mathrm{E}\right)$.

2. The height levels required by the HYSPLIT model were computed from selected pressure levels from $850 \mathrm{hPa}$ to $450 \mathrm{hPa}$ in steps of $50 \mathrm{hPa}$, which were transformed to altitude using the barometric equation and assuming a standard International Civil Aviation Organization (ICAO) atmosphere. 
3. A 10-day backward trajectory was calculated for each level and selected event. Calculations provided hourly coordinates of the air parcel and hourly meteorological data relevant to this study: mixed layer depth, relative humidity and specific humidity.

205

flagged as "attributed". However, if the uptake happened above the mixed layer height, then it was not possible to be certain that the moisture came from the area below the air parcel and the uptake was flagged as "above". In case $\Delta \mathrm{q}(\mathrm{t})$ $<=-0.1 \mathrm{~g} \cdot \mathrm{kg}^{-1}$, then the decrease was assumed to be caused by precipitation. 225 Wang et al. (2017) reported that moisture sources were sensitive to the $\Delta q(t)$ threshold value to decide whether a positive $\Delta q(t)$ should be considered or not a moisture uptake. In the present study, $\Delta q(t)$ threshold was set to $0.1 \mathrm{~g} \cdot \mathrm{kg}^{-1}$. Although in Sodemann et al. (2008) a $\Delta q(t)$ threshold of $0.2 \mathrm{~g} \cdot \mathrm{kg}^{-1}$ was adopted, the temporal resolution of uptake identification was 6 hours, whereas in the 
for the finer $\Delta q(t)$ values found for 1 hour resolution in comparison to 6 hours resolution, the threshold of $0.1 \mathrm{~g} \cdot \mathrm{kg}^{-1}$ was considered suitable. Details of this analysis are given in Appendix A.

Finally, once all moisture sources were identified, the relative contribution tion, these contributions were classified in different regional divisions (Figure2), including the Atlantic (ATL), Western Mediterranean (WM), Eastern Mediterranean (EM), Continental Europe (EUR), Africa (AFR) and Polar (POL) regions. Sources falling outside these regional divisions were considered as "not classified sources".

\section{Results}

\subsection{Rainfall stable isotope composition and $L M W L$}

The isotopic content of weekly rainfall samples $(n=125)$ collected in the Vallcebre Research catchments can be found in Table 1 . The $\delta D$ and $\delta^{18} O$ data varied greatly; $\delta D$ ranged from $-152.2 \%$ to $4.4 \%$ and $\delta^{18} O$ from $-19.1 \%$ to $-0.8 \%$. This variability was reflected in the relatively high values of standard deviations. The minimum value of d-excess was negative, which is not common. A d-excess value smaller than $3 \%$ is considered anomalous due to possible postprecipitation interference (Harvey \& Welker, 2000) or a local isolated air mass (Yuan \& Miyamoto, 2008).

The scatter plot between $\delta D$ and $\delta^{18} O$ is useful, since it describes how the heavy isotope components behave in different ways (Dansgaard, 1964) and how different the measurements from the GMWL are. In order to calculate the LMWL for Vallcebre, isotopic composition of weekly rainfall was used. Isotopic values $\left(\delta D\right.$ and $\left.\delta^{18} O\right)$ were weighted by the amount of rainfall corresponding to each sample (Figure 3). The local meteoric water line was calculated by an ordinary least-squares fitting method with an $\mathrm{R}^{2}$ adjusted value of $0.96(\mathrm{p}<0.01)$. 
The equation obtained was:

$$
\delta D=7.9 \cdot \delta^{18} O+12.9
$$

\subsection{Seasonality of rainfall signature}

260 ture (weekly samples) and its relationship with weekly mean air temperature and rainfall amount. The maximum $\delta^{18} O$ was recorded in summer $(-0.8 \%)$; the minimum, in winter $\left(-19.1 \%\right.$ ). The intra-annual trend of the $\delta^{18} O$ precipitation signature roughly follows the mean monthly air temperature trend (Figure 265 4a). A moderate correlation $\left(\mathrm{R}^{2}=0.44, \mathrm{p}<0.01\right)$ was found between air temperature and the $\delta^{18} O$ precipitation signature at Vallcebre (Figure $4 \mathrm{~b}$ ). The correlation suggested a reliable relationship between air temperature and isotopic composition of precipitation, which is known as the temperature effect. When precipitation was considered (Figures 4 and $4 \mathrm{~d})$, no correlation $\left(\mathrm{R}^{2}=\right.$ maximum in July (-3.0\%). d-excess values ranged from $10.4 \%$ in an event in July to $22.2 \%$ in November. In terms of rainfall characteristics, 8 out of 15 events were classified as non-frontal convective. Most of the selected events (12 out of 15) had a V-shaped isotopic trend, showing that in the first steps of the 285 $0.01, \mathrm{p}=0.19)$ was found between rainfall amount and its $\delta^{18} O$ content. In this case, the amount effect, which implies depleted precipitation in heavy isotopes as rainfall depth increases, was not seen. The $\delta D$ precipitation signature followed the same trend as $\delta^{18} O$, with a minimum value of $-152.2 \%$ during winter and a maximum of $4.4 \%$ in summer.

\subsection{Intra-event dynamics}

Out of all the rainfall events identified in the study period, 15 events (with at least 4 rainfall samples taken by the sequential rainfall sampler, e.g. corresponding to at least $20 \mathrm{~mm}$ of rainfall) were selected to evaluate the different isotopic trends and types of precipitation observed (Table 2). $\delta^{18} O$ mean values for the selected events ranged from their minimum in April (-10.8\% ) to their rainfall event depletion of heavy isotopes occurred. However, in the final stages 
of the event, precipitation was enriched by heavy isotopes and isotopic composition recovered to be similar to that at the beginning of the rainfall event. Only two events followed an L-shaped isotopic trend. The third isotopic trend type with nearly constant isotopic content was identified once, which led to minimum values for the standard deviation of $\delta^{18} O$ and $\delta D$. The embedded graph in Figure 5 suggests that half of the 15 events analysed fell above the LMWL, showing a d-excess higher than $12.9 \%$. Two groups of events could be identified: events with d-excess values close to the LMWL and events with values further away from the LMWL. Although half of the events were above the LMWL, this does not mean that all individual samples during a rainfall event showed the same trend. To show intra-event scale variability, intra-event scale samples are given (Figure 5) for three selected events that had different isotopic trends: Events 2, 9 and 15. Event 2 corresponded to a constant isotopic trend (Figure 6b) and showed less variability. The samples are concentrated in the same zone in Figure 5 and aligned with a slope of 4.3, which suggests evaporation of raindrops, although the precipitation accumulated for each sample. Events 9 and 15, in contrast, had great variability and corresponded to L-shaped and V-shaped isotopic trends, respectively (Figures $7 \mathrm{~b}$ and $8 \mathrm{p}$ ). Both events can be associated with equilibrium fractionation effects, as their isotopic variability 305 approximately follows the linear relationship of the LMWL with a slope of 7.6 for Event 9 and 7.5 for Event 15 (Figure 5). However, Event 15 is partly affected by kinetic fractionation since its $\mathrm{V}$-shape also arise in the $\delta^{18} O$ and $\delta D$ plane, not following then the LMWL as Event 9 does (Figure 5). It can be seen in the last sample of Event 15, far from the LMWL and with small precipitation amount.

\subsection{Moisture source attribution}

Two or three representative instants of each event were selected to calculate moisture attribution depending on d-excess trend (e.g. three specific instants if the d-excess decrease is gradual -at the beginning, in the middle and at the 
of some of the events was close to the GDAS data temporal resolution, different trajectory calculations were still considered to discard abrupt changes of moisture sources. A total of 324 trajectories were calculated for the 15 selected events. 113 of them (34.8\%) met the conditions described in Section 2.5 to allow the computing of the moisture uptake history of the backward trajectories. The frequency plot of all the valid trajectories (Figure 9a) had two features: i) most of the trajectories came from the west, as expected from global atmospheric circulation, ii) the entry to Vallcebre Research Catchments was concentrated in two sectors, namely the Gulf of Bizkaia and the Catalan coastline (Figure 9a). From all 113 trajectories considered, a $0.5^{\circ} \times 0.5^{\circ}$ grid covering their extent was drawn and the contribution to the final moisture from each cell of the grid was calculated (Figure 9p). Results showed that $56 \%$ of the moisture present above the Vallcebre catchments could be attributed to one of the six moisture source regions described in Figure 2, 40\% of the moisture could not be attributed to any source region because it corresponded to uptakes above the boundary layer. Finally, a remaining moisture amount was categorized as unknown in cases when the air parcel was not completely dry at the start position of the trajectory, representing $4 \%$ of the moisture. From the known moisture sources, the regions that contributed most were: the Western Mediterranean (58\%), the 335 Atlantic area (25\%) and the African region (14\%). Contributions from the other regions were less than $1 \%$ each. Moisture source attribution at the event scale (Table 3) showed that most of the events with a high d-excess were related to a predominance of air masses with a Western Mediterranean and African origin (Events 2, 3, 4, 11, 15). However, this did not hold for Events 6 and 7. Event mean d-excess of $11.0 \%$, which may be related to the combination of WM and ATL sources. Event 10 had a mixture of Western Mediterranean and Atlantic moisture contribution sources with little influence from African and European regions. This combination may explain the d-excess value of 11.9\%o. In Event 1, 345 d-excess values varied slightly, from $10.0 \%$ to $13.0 \%$, which was also reflected at intra-event scale moisture source attribution (Table 4). In addition, mean 
d-excess value of $11.1 \%$ may be related to a mixture of WM and ATL source regions.

\subsection{Evaluation of the moisture source attribution method} evaluate its performance in the study area. As shown in Figure 10, a period of two days back in time was enough to identify at least half the moisture present above the Vallcebre Research Catchments. The mean increase of the known fraction was $23 \%$ per day during the first $72 \mathrm{~h}$ of backward simulation, $6 \%$ day from $72 \mathrm{~h}$ to $168 \mathrm{~h}$, and only $2 \% /$ day during the last $72 \mathrm{~h}$. However, identifying half the moisture present above the Vallcebre Research Catchments was not equivalent to knowing $50 \%$ of the moisture sources, because the known fraction includes the uptakes tagged as above (i.e. not taken from the source region). Consequently, the known fraction has to be divided into two parts: attributed and above. The $50 \%$ barrier of the attributed fraction was overtaken at day 5 , when the remaining unknown fraction had a value of $16 \%$. This study also showed that 10-day backward trajectories were not sufficient to acquire full knowledge of the moisture origin above Vallcebre. Still, it was consistent with mean water residence time in the atmosphere $\sim 9$ days.

3.6. Intra-event scale variations of characteristic events

Three characteristic events (with different isotopic trends) were analysed more fully. These were selected beforehand because of the clarity of their $\delta^{18} \mathrm{O}$ isotopic trend. This clarity would show their intra-event variability properly (Figure 5).

\subsubsection{Constant trend: Event 2, 30th July 2011}

A cold air intrusion, with temperatures between $-15^{\circ} \mathrm{C}$ and $-10^{\circ} \mathrm{C}$ at the 500 hPa level, characterized the last two days of July 2011. This relatively low temperature at that height induced an unstable atmosphere favouring storms and precipitation. The event started at 12.50 UTC and ended at 15.20 UTC, leaving 
fied as non-frontal convection. Despite small fluctuations, air temperature and relative humidity presented a decreasing trend. Although three different peaks were observed (Figure 6a), the isotopic composition of precipitation was nearly constant. The initial $\delta^{18} O$ was $-6.3 \%$ and experienced a slight enrichment to 380 dard deviation of $\delta^{18} O$ and $\delta D$ in accordance with the constant isotopic trend identified. The d-excess increased from an initial value of $19.4 \%$ to $21.1 \%$ and then decreased to a final value of $14.4 \%$. Two different instants of the event were selected to calculate the backward trajectories and the moisture sources: one at the beginning of the event and another at the end. For this event, $73 \%$ of the moisture origin could be identified: $35 \%$ corresponded to the Western Mediterranean area and 29\% to the European region; the rest was attributed to the Atlantic region (Table 44. The two selected instants had similar trajectory paths, but their contribution differed. In the first one, the contribution from the Western Mediterranean region was dominant, whereas in the second one the European region was the main contributor (Figure 6c and 6d).

\subsubsection{L-shaped trend: Event 9, 19th January 2013}

This event, lasting five days, from 18th to 21st January 2013, was due to a cold front. An anomaly in the medium tropospheric level thermal field was observed, with temperatures below $-25^{\circ} \mathrm{C}$ at $500 \mathrm{hPa}$. At surface level, a deep low-pressure system with an associated cold front went from west to east over the Iberian Peninsula. The precipitation started on 19th January at 06.15 UTC and lasted more than 15 hours until 21.50 UTC, giving $37.8 \mathrm{~mm}$ with a mean intensity of $2.4 \mathrm{~mm} / \mathrm{h}$ (Figure $7 \mathrm{a}$ ). Air temperature followed a steadily decreasing trend from $5^{\circ} \mathrm{C}$ to $1^{\circ} \mathrm{C}$, whereas relative humidity was mostly constant at $94 \%$ during the event, except at the start of it where it momentarily decreased to $83 \%$. A maximum $\delta^{18} \mathrm{O}$ of $-6.1 \%$ was observed at the start of the rainfall event. The precipitation's heavy-isotope content fell steadily, reaching a $\delta^{18} O$ of $-12.9 \%$ at the end of the event (Figure $7 \mathrm{~b}$ ). The $\delta^{18} O$ steady fall behaves sim- 

nearly $10 \mathrm{~mm}$ in 5 minutes (Figure 8 a). Air temperature and relative humidity values followed opposite trends. On one hand, the former experienced a sharp decrease from $16.5^{\circ} \mathrm{C}$ to $11.5^{\circ} \mathrm{C}$ coinciding with the bulk of rainfall and kept 


\section{Discussion}

\subsection{Stable Isotope composition and local meteorological variables}

Weekly isotopic values of rainfall sampled in the Vallcebre Research Catchments showed that the classification of precipitation as either enriched or depleted was not straightforward. The Western Mediterranean region is under the influence of the Mediterranean Sea and the Atlantic Ocean. The two sources have different isotopic content, enriched values for the Mediterranean and depleted for the Atlantic region (Celle-Jeanton et al., 2001). The mean value of $-7.2 \%$ for $\delta^{18} \mathrm{O}$ observed in Vallcebre was consistent with this mixed influence. ${ }_{460}$ Celle-Jeanton et al. (2001) also obtained for Barcelona a mean $\delta^{18} O$ value of $5.5 \%$ for the period from 1985 to 1991 . A possible explanation for the difference between these two isotopic values is the influence of altitude effect (Dansgaard, 1964 Kendall \& McDonnell, 1998). This factor, considering the altitude dif- 
ference between Barcelona and the Vallcebre Research Catchments, $0 \mathrm{~m}$ asl and $1200 \mathrm{~m}$ asl, respectively, probably explains the lighter precipitation found in the latter. In addition, comparing $\delta^{18} O$ values for Barcelona and Vallcebre Research Catchments results in a $\delta^{18} \mathrm{O}$ depletion of $0.2 \%$ /100 m, which is consistent with Gat (2010). Another factor of differentiation between Barcelona and Vallcebre is temperature at the sampling site. Relationships between surface air temperature at the sampling site and $\delta^{18} O$ have been widely studied (e.g. Dansgaard, 1964, Araguás-Araguás \& Diaz Teijeiro, 2005, Yu et al., 2016). All these studies showed an enrichment of heavy isotopes in precipitation as temperature increased. Temperature, therefore, also explains the more depleted values observed in Vallcebre than at the Barcelona station, as mean annual temperature is much lower in Vallcebre. For Vallcebre, a weak-to-moderate correlation with a $\mathrm{R}^{2}$ of 0.44 between $\delta^{18} O$ and temperature was found. This relationship showed a slope of $0.4 \% 0 /{ }^{\circ} \mathrm{C}$ and an intercept of $-10.8 \%$. It was nearly the same relationship as the one obtained by Araguás-Araguás \& Diaz Teijeiro (2005) for the Madrid-Retiro station. However, in this latter study, the $\mathrm{R}^{2}$ value was much higher (0.9) because the relationship was drawn from monthly data instead of weekly data. Dansgaard (1964) pointed out that the variations experienced by individual precipitation compositions are smoothed when average compositions are compared over a sufficiently long period of time. The influence of rainfall amount on the isotopic composition of precipitation was tested. However, no correlation was found, suggesting that, at Vallcebre, temperature played a more significant role than rainfall amount in the heavy isotope content of precipitation. Weekly samples were also used to retrieve a LMWL. The one obtained in this study Eq. (3) corroborates the one calculated by Celle (2000) for the Western Mediterranean (WMMWL):

$$
\delta D=8 \cdot \delta^{18} O+13.7
$$

490 d-excess values confirm the singularity of the Western Mediterranean region (Celle-Jeanton et al. 2001), compared to 22\% (Gat \& Carmi, 1970) for the Eastern Mediterranean and $10 \%$ of the GMWL, characteristic of Atlantic sources. 
The difference in d-excess between Eq. (3) and Eq. (4) may be explained by the Atlantic moisture sources affecting the Vallcebre Research Catchments more. However, the d-excess value obtained in this study falls within the range of d-excess values measured by Huyghe et al. (2018) for the southern Pyrenees $(7 \% 0-14 \%)$.

\subsection{Selected rainfall events}

Of the 15 rainfall events selected, 3 of them, representing the three main types of intra-event isotopic trends, were analysed in depth in this study. Most of the 15 events had a V-shaped isotopic trend (Table 2), although not all of them had a totally clear trend. Some of the events had, first, a depletion in heavy isotopes, then a constant trend until enrichment occurred. Figure $8 \mathrm{~b}$ shows a clear example of a trend with final enrichment, in this case reaching a similar value to the initial value. However, not all enrichments were so clear. Some of them, indeed, showed much lower enrichment, but were still considered Vshaped, as Celle-Jeanton et al. (2001) also found. Half of the events fell above the LMWL (Figure 5), which may be related to reduced subcloud evaporation effects on heavy rainfall events and condensation occurring at a lower temperature, resulting in higher d-excess values (Guan et al., 2013). The V-shaped trends identified in this study were usually associated with convective or shower-type precipitation, as in Celle-Jeanton et al. (2004). The L-shaped isotopic trend, which involves steady depletion of heavy isotopes, was usually associated with the passage of a cold front (Gedzelman \& Lawrence, 1990; Celle-Jeanton et al., 515 2004), as found for the two events of that type observed in this study (Table 2). Finally, the only event with a constant isotopic trend corresponded to convective precipitation, as also observed by Celle-Jeanton et al. (2004).

\subsection{Intra-event scale variations of three characteristic events}

\subsubsection{Event 2, constant trend}

${ }_{520}$ Miyake (1968) argued that the constant trend was caused by precipitation forming at an unvarying height. This explanation may not fit with the type 
of precipitation found in this study for Event 2 (Figure 6a), as this was convective. In convective events, the height where precipitation forms may vary much more than in stratiform precipitation events. Celle-Jeanton et al. (2004), however, suggested that the constant trend may be due to the steady state condensation/rain-out process attained by convection. This explanation is more consistent with the characteristics found for Event 2. Although rain rates in this event were relatively high, the isotopic signature of precipitation was not affected by the amount effect, since more depleted values would be expected. In the present case, the enriched mean of $-5.7 \%$ of $\delta^{18} O$ may be explained by the slope of 4.3 obtained from individual samples (Figure 5), indicating evaporation effects with kinetic fractionation (Dansgaard, 1964). In addition, relative humidity values showed unsaturated air conditions. These effects tend to enrich precipitation in heavy isotopes. Regarding d-excess variability, although there were changes in the moisture sources reflected by the increase of the European source (Table 4), the small difference between the two selected instants to calculate backward trajectories, suggests that d-excess trend was governed mostly by sub-cloud processes. In this case, re-evaporation, yields a decrease of d-excess (Julian et al., 1992, Risi et al., 2010) which would explain the d-excess decreasing trend at the end of the event. From an event point of view, moisture sources showing high influence of the Western Mediterranean and Europe areas were in accordance with the high d-excess values found.

\subsubsection{Event 9, L-shaped trend}

In the L-shaped isotopic trend of Event $9, \delta^{18} O$ decreased steadily from a temporal point of view (Figure $7 \mathrm{a}$ ) and following the LMWL in the $\delta^{18} O$ vs $\delta D$ plane (Figure 5). The latter suggests that isotopic variations may mostly be associated to equilibrium fractionation alone rather than kinetic fractionation. In this case an assumption of vapor/liquid equilibrium during rainout occurring at progressively lower temperatures (Gat, 1996) fits with the $\delta^{18} O$ evolution and air temperature decrease (Figures $7 \mathrm{a}$ and $7 \mathrm{~b}$ ). In addition, the evolution of an isotopic trend can be related, among others, to rainfall intensity, 
conditions below the cloud or the weather system (Risi et al. 2010, Aemisegger et al. 2015; Muller et al., 2015). In the present case, the decreasing trend of $\delta^{18} O$ could be explained by the associated passage of a cold front. As the cold front approaches the sampling site, the local height where the precipitation is formed tends to increase, resulting in the precipitation containing fewer heavy isotopes, as discussed by Gedzelman \& Lawrence (1990). During Event 9, the peak of precipitation and its most depleted value were consistent with the passage of the cold front (Figures $7 \mathrm{a}$ and $7 \mathrm{~b}$ ). The initial enriched values of $\delta^{18} \mathrm{O}$ may be due to evaporative effects that occurred when the sub-cloud layer was not saturated (Ehhalt et al., 1963) as indicated by the relative humidity values (Figure $7 \mathrm{a}$ ). At the end of the event, a constant trend was reached, which is usual after a decreasing trend of heavy isotopes (Muller et al., 2015). In this case, the character of the precipitation at the last stages of the event (Figure ${ }_{565}$ 7a) was consistent with the suggestion made by Miyake (1968). The d-excess followed a trend similar to $\delta^{18} O$. However, the first and the middle part of the event followed a nearly constant trend in agreement with the aforementioned rainout conditions (Gat, 1996). In this period of the event, d-excess fluctuated from $11.0 \%$ o to $12.8 \%$, which could be attributed, at some extent, to the increasing influence of the Western Mediterranean moisture source in the middle of the event yielding a higher d-excess, in comparison to the start of it when the Western Mediterranean contribution was barely residual in front of Atlantic source. In the last part of the event, however, the d-excess decrease could be explained due to a sub-cloud process. Evaporation is unlikely due to high rela(Guan et al. 2013), which is in accordance with the precipitation type found in the last stages of the event, offers a possible explanation for the d-excess final trend. Overall, if the event is taken as a whole regarding moisture sources, the mean d-excess value of $11.0 \%$ is in agreement with the Atlantic predominant moisture source with some Western Mediterranean influence. 


\subsubsection{Event 15, V-shaped trend}

V-shaped isotopic trends usually appear in convective events (Muller et al. 2015, Risi et al. 2010), which was the case of Event 15. The initial enriched values of $\delta^{18} O$ may result from the raindrops production in low-altitude clouds affected by evaporation during their path to the surface (Muller et al. 2015) and by the weak character of precipitation which made raindrops more susceptible to evaporation (Risi et al. 2010). In the present case, both explanations fit with the unsaturated air at the surface and the low rain rates during the initial stages of the event (Figure 8a). However, when the bulk of the precipitation happened, an abrupt depletion in heavy isotopes occurred (Figures 8p and 8b). This corresponded with the increased height of rain formation: a similar process as for Event 9. However, in this case convection was responsible for increasing the altitude of rain formation. Indeed, when convection cells reach their top height, more depleted values of $\delta^{18} O$ are expected (Muller et al., 2015). In Event 15 , the minimum $\delta^{18} O$ value coincided with the maximum rainfall intensity, which is consistent with Muller et al. (2015). In addition, although without air saturated conditions (Figure $8 \mathrm{a}$ ), evaporative effects were neglected by the rain intensity diminishing the interaction with ambient air (Gat, 1996). Therefore, an amount effect was apparent, with more depleted values as rainfall intensity increased. Furthermore, a sharp decrease of air temperature also coincides with the $\delta^{18} O$ depletion (Figures $8 \mathrm{a}$ and $8 \mathrm{~b}$ ). The end of the event was characterized by an enrichment in heavy isotopes, which is usually related to evaporative conditions. However, relative humidity values showed saturated air conditions, which would limit evaporation. In this case, the final increasing trend could be related to residual precipitation formed at lower elevation (Celle-Jeanton et al. 2004) or diffusive exchange between falling drops and water vapour near the ground (Risi et al., 2010). Regarding d-excess evolution, it followed a steadily decrease trend. Moisture sources were similar for the different selected starting points because of their small time separation. Thus, d-excess changes were mainly governed by sub-cloud processes. However, moisture sources for the 
whole event were in agreement with the mean d-excess value of $12.0 \%$, resulting from a combination of Western Mediterranean and Atlantic sources (Figures 86, 8d, 8p and Tables 3 and 44. Overall, final low d-excess values may be due to diffusive exchange between raindrops and the surrounding vapor (Risi et al. 615 2010), which is very efficient at high relative humidity.

\subsection{Moisture source attribution for the selected events}

In addition to Events 2, 9 and 15, the moisture sources were calculated for the rest of the selected events (Table 2). As Celle-Jeanton et al. (2001) pointed out, d-excess values of $14 \%$ are characteristic of the Western Mediterranean area, which ranges from $10 \%$ (Atlantic) to $22 \%$ (Eastern Mediterranean). Table 3 summarizes the contribution of different moisture sources and shows that most of the d-excess values of the events with predominance of WM contributions range from $14 \%$ to $22 \%$, which may demonstrate the influence of moisture sources on d-excess values. However, when analysing these results, it is important to take into account the limitations of the attribution methodology used in this study, as specified by Sodemann et al. (2008), in particular the omission of the effects of convection, turbulence, rainwater evaporation or evaporation occurring over land. In addition, sub-cloud processes may play an important role in d-excess variability, as well as moisture source changes. The total attributed moisture fraction, $56 \%$, was lower than those reported in other studies such as $66 \%$ for Greenland (Sodemann et al. 2008), 68\% for Israel (Pfahl \& Wernli 2008 ) and 85-91\% for the NW Mediterranean region (Winschall et al., 2014). The lower values found in this study may be due to the differences or simplifications applied in the moisture attribution method proposed by Sodemann et al. (2008). The main differences were the following: first, the way the atmosphere was vertically differentiated in this study was less precise because height levels were used rather than pressure levels; second, noise areas (with moisture uptakes below a small threshold) were those with uptakes lower than $0.1 \mathrm{~g} \cdot \mathrm{kg}^{-1}$, whereas in the other studies uptakes lower than $0.2 \mathrm{~g} \cdot \mathrm{kg}^{-1}$ were considered as noise. This latter simplification may explain the difference between the unknown moisture 
fraction (3.7\% in this study) and the $14 \%$ obtained by Sodemann et al. (2008). Of the $56 \%$ of the moisture fraction that could be attributed, nearly $58 \%$ of it corresponded to a Western Mediterranean source, followed by the Atlantic Ocean with $\sim 25 \%$. These percentages were consistent with the mean isotopic values in Table 1, confirming the influence of both sources to give $\delta^{18} O$ a mean value of $-7.2 \%$. In addition, the d-excess value of $13.2 \%$ confirmed the higher influence of the Western Mediterranean sources, at least for the 15 events analysed. In Figure 10, the overall results from the backward trajectory calculations and moisture attributions showed that, in only two days, the unknown fraction of the moisture present above Vallcebre was reduced by half. However, to overcome $50 \%$ of the attributed fraction, five days back in time were needed. In the HYSPLIT interface used, it was not possible to stop a backward trajectory when a specific humidity of $0 \mathrm{~g} \cdot \mathrm{kg}^{-1}$ was reached or at a value that we considered dry enough. For this reason, a fixed 10-day backward time was employed, similar to Pfahl \& Wernli (2008) and Winschall et al. (2014). Pfahl \& Wernli (2008) related d-excess to the mean moisture source 2-meter relative humidity (RH2m), obtaining close correlation. The correlation was tested with a different number of trajectories, depending on their attributed fraction percentage ( $>60 \%,>40 \%$ and $>20 \%$ ); all of them showed nearly the same correlation. This result may be useful in selecting the backward time considered for trajectory calculations, in order to get a first approach and to test whether a correlation between RH2m and d-excess exists. This means that, taking into account the results observed in Figure 10, between two and three days back in time would be enough to establish or test a correlation between moisture source mean relative humidity and d-excess. Figure 10 shows that a 10-day backward trajectory lasted long enough to know practically the entire origin of the moisture (above Vallcebre), which is the sum of the moisture contributions tagged above and attributed. The slope for the last hours of the backward trajectory calculations and its steady decrease over time suggested that at least two more days back in time would be needed to reduce the unknown fraction to zero. 


\section{Conclusions}

The following conclusions emerge from the results obtained in this study.

- The isotopic signatures of meteoric waters in Vallcebre are influenced by the Western Mediterranean and Atlantic Ocean. This results in $\delta^{18} O$ and $\delta D$ mean values that are neither systematically enriched nor depleted. For the events selected, the Western Mediterranean is the major contributor to the moisture above Vallcebre $(58 \%)$, followed by the Atlantic Ocean (25\%) and the African region (14\%).

- A moderate, but significant, correlation suggests that temperature does have an effect on the isotopic signature, whereas no correlation was found for the amount effect.

- Most of the events selected had a V-shaped isotopic trend, followed by those with L-shaped and constant trends, respectively. The latter could be found in some events, in the middle part of the $\mathrm{V}$-shaped trend or during the final stages of an L-shaped isotopic trend.

- Isotopic variability at intra-event time scale was mostly governed by subcloud processes, air temperature and relative humidity near the ground and the type of weather system. Moisture sources and their changes, however, were not sufficient to explain completely intra-event variabilities, but were generally in accordance with event mean d-excess values.

- The 10-day limit for the backward trajectory calculations is enough to classify nearly $96 \%$ of the moisture present above Vallcebre Research Catchments.

Despite the relatively small number of events selected and the simplifications used in the source region attribution method, moisture origin attribution achieved 56\%. Further studies using this methodology with a larger number of events could provide a more comprehensive analysis of isotopic variability in precipitation at the event scale. In addition, intra-event scale analysis of 
weather events in NE Spain could be done by using limited-area isotope model simulations.

\section{Acknowledgements}

This study derived from a first author internship in the Surface Hydrology and Erosion group at IDAEA-CSIC. Generous support from members of the group is acknowledged. The authors are grateful to the NOAA Air Resources Laboratory (ARL) for the provision of the HYSPLIT transport and dispersion model and READY website (http://www.ready.noaa.gov) used in this publication. This study was supported by the TransHyMed (CGL2016-75957R AEI/FEDER, UE), MASCC-DYNAMITE (PCIN-2017-061/AEI), CGL201565627-C3-2-R (MINECO/FEDER) and CGL2016-81828-REDT (MINECO). The authors would also like to acknowledge the helpful and constructive suggestions and comments from three anonymous reviewers that have improved this study.

\section{References}

Aemisegger, F., Spiegel, J., Pfahl, S., Sodemann, H., Eugster, W., \& Wernli, H. (2015). Isotope meteorology of cold front passages: A case study combining observations and modeling. Geophysical Research Letters, 42, 5652-5660.

Araguás-Araguás, L., \& Diaz Teijeiro, M. (2005). Isotope composition of precipitation and water vapour in the iberian peninsula: first results of the spanish network of isotopes in precipitation. International Atomic Energy Agency Technical Report, 1453, 173-190.

Araguás-Araguás, L., Froehlich, K., \& Rozanski, K. (2000). Deuterium and oxygen-18 isotope composition of precipitation and atmospheric moisture. Hydrological processes, 14, 1341-1355.

Cayuela, C., Latron, J., Geris, J., \& Llorens, P. (2018). Spatio-temporal variability of the isotopic input signal in a partly forested catchment: Implications for hydrograph separation. Hydrological Processes, . 
Celle, H. (2000). Caractérisation des précipitations sur le pourtour de la Méditerranée occidentale. Approche isotopique et chimique.. Ph.D. thesis $\mathrm{PhD}$, Université d'Avignon et des Pays de Vaucluse, Avignon, France.

Celle-Jeanton, H., Gonfiantini, R., Travi, Y., \& Sol, B. (2004). Oxygen-18 variations of rainwater during precipitation: application of the Rayleigh model to selected rainfalls in Southern France. Journal of Hydrology, 289, 165-177.

Celle-Jeanton, H., Travi, Y., \& Blavoux, B. (2001). Isotopic typology of the precipitation in the Western Mediterranean region at three different time scales. Geophysical Research Letters, 28, 1215-1218.

Craig, H. (1961). Isotopic variations in meteoric waters. Science, 133, 17021703.

Dansgaard, W. (1964). Stable isotopes in precipitation. Tellus, 16, 436-468.

Draxler, R., \& Rolph, G. (2003). HYSPLIT (HYbrid Single-Particle Lagrangian Integrated Trajectory). NOAA Air Resources Laboratory, Silver Spring, MD. Model access via NOAA ARL READY Website.

Ehhalt, D., Knott, K., Nagel, J., \& Vogel, J. (1963). Deuterium and oxygen 18 in rain water. Journal of Geophysical Research, 68, 3775-3780.

Froehlich, K., Gibson, J., \& Aggarwal, P. (2002). Deuterium excess in precipitation and its climatological significance. Technical Report No. IAEA-CSP$13 / \mathrm{P}$

Gallart, F., Balasch, J., Regüés, D., Soler, M., \& Castelltort, X. (2005). Catchment dynamics and river processes: Mediterranean and other climate regions. In Catchment dynamics in a Mediterranean mountain environment: the Vallcebre research basins (Southeastern Pyrenees) II: temporal and spatial dynamics of erosion and steam sediment transport (pp. 17-24). Elsevier BV.

Gat, J. (2010). Isotope hydrology: a study of the water cycle volume 6. World scientific. 
Gat, J., \& Carmi, I. (1970). Evolution of the isotopic composition of atmospheric waters in the Mediterranean Sea area. Journal of Geophysical Research, 75, 3039-3048.

Gat, J. R. (1996). Oxygen and hydrogen isotopes in the hydrologic cycle. Annual Review of Earth and Planetary Sciences, 24, 225-262.

Gat, J. R., \& Gonfiantini, R. (1981). Stable isotope hydrology deuterium and oxygen-18 in the water cycle. International Atomic Energy Agency (IAEA): $I A E A$, .

Gedzelman, S. D., \& Lawrence, J. R. (1990). The isotopic composition of precipitation from two extratropical cyclones. Monthly Weather Review, 118, 495-509.

Good, S. P., Mallia, D. V., Lin, J. C., \& Bowen, G. J. (2014). Stable isotope analysis of precipitation samples obtained via crowdsourcing reveals the spatiotemporal evolution of superstorm sandy. PloS one, 9, e91117.

Guan, H., Zhang, X., Skrzypek, G., Sun, Z., \& Xu, X. (2013). Deuterium excess variations of rainfall events in a coastal area of south Australia and its relationship with synoptic weather systems and atmospheric moisture sources. Journal of Geophysical Research: Atmospheres, 118, 1123-1138.

Guo, X., Tian, L., Wen, R., Yu, W., \& Qu, D. (2017). Controls of precipitation $\delta^{18} \mathrm{O}$ on the northwestern Tibetan Plateau: A case study at Ngari station. Atmospheric Research, 189, 141-151.

Harvey, F., \& Welker, J. (2000). Stable isotopic composition of precipitation 775 in the semi-arid north-central portion of the US Great Plains. Journal of Hydrology, 238, 90-109.

Huyghe, D., Mouthereau, F., Sebilo, M., Vacherat, A., Ségalen, L., Richard, P., Biron, P., \& Bariac, T. (2018). Impact of topography, climate and moisture 
sources on isotopic composition $\left(\delta^{18} \mathrm{O} \& \delta \mathrm{D}\right)$ of rivers in the Pyrenees: Implications for topographic reconstructions in small orogens. Earth and Planetary Science Letters, 484, 370-384.

Julian, J. C.-S., Araguas, L., Rozanski, K., Benavente, J., Cardenal, J., Hidalgo, M., Garcia-Lopez, S., Martinez-Garrido, J., Moral, F., \& Olias, M. (1992). Sources of precipitation over south-eastern Spain and groundwater recharge. an isotopic study. Tellus B, 44, 226-236.

Kendall, C., \& McDonnell, J. (1998). Isotope Tracers in Catchment Hydrology. Elsevier Science.

Krklec, K., Domínguez-Villar, D., \& Lojen, S. (2018). The impact of moisture sources on the oxygen isotope composition of precipitation at a continental site in central Europe. Journal of Hydrology, 561, 810-821.

Latron, J., Llorens, P., Estringana, P. G., \& Planasdemunt, M. R. (2014). Estudio y modelización de la dinámica hidrológica de un ambiente mediterráneo de montaña. síntesis de los resultados obtenidos a lo largo de 25 años de investigaciones en las cuencas de Vallcebre (pirineo oriental). In Geoecología, cambio ambiental y paisaje: homenaje al profesor José María García Ruiz (pp. 183-194). Instituto Pirenaico de Ecología.

LeGrande, A. N., \& Schmidt, G. A. (2006). Global gridded data set of the oxygen isotopic composition in seawater. Geophysical research letters, 33.

Lekshmy, P., Midhun, M., \& Ramesh, R. (2018). Influence of stratiform clouds on $\delta \mathrm{D}$ and $\delta^{18} \mathrm{O}$ of monsoon water vapour and rain at two tropical coastal stations. Journal of Hydrology, .

Liotta, M., Bellissimo, S., Favara, R., \& Valenza, M. (2008). Isotopic composition of single rain events in the central Mediterranean. Journal of Geophysical Research: Atmospheres, 113.

805

Llorens, P., Gallart, F., Cayuela, C., Planasdemunt, M. R., Casellas, E., Molina, A., de las Heras, M. M., Bertran, G., Costa, E. S., \& Latron, J. (2018). What 
have we learnt about Mediterranean catchment hydrology? 30 years observing hydrological processes in the Vallcebre research catchments. Cuadernos de investigación geográfica/Geographical Research Letters, (pp. 475-502).

catalogue.ceda.ac.uk/uuid/267264a0036052fe71f5f25e384f0339. Accessed 18 February 2019.

Miyake, Y. (1968). An isotopic study on meteoric precipitation. Papers in Meteorology and Geophysics, 19, 243-266.

Muller, C. L., Baker, A., Fairchild, I. J., Kidd, C., \& Boomer, I. (2015). Intraevent trends in stable isotopes: Exploring midlatitude precipitation using a vertically pointing micro rain radar. Journal of Hydrometeorology, 16, 194213.

Pfahl, S., \& Sodemann, H. (2014). What controls deuterium excess in global precipitation? Climate of the Past, 10, 771-781.

Pfahl, S., \& Wernli, H. (2008). Air parcel trajectory analysis of stable isotopes in water vapor in the eastern Mediterranean. Journal of Geophysical Research: Atmospheres, 113.

825

Ren, W., Yao, T., \& Xie, S. (2017). Key drivers controlling the stable isotopes in precipitation on the leeward side of the central Himalayas. Atmospheric Research, 189, 134-140.

Rindsberger, M., Jaffe, S., Rahamim, S., \& Gat, J. (1990). Patterns of the isotopic composition of precipitation in time and space: data from the israeli

Risi, C., Bony, S., Vimeux, F., Chong, M., \& Descroix, L. (2010). Evolution of the stable water isotopic composition of the rain sampled along sahelian squall lines. Quarterly Journal of the Royal Meteorological Society, 136, 227-242. 
Rozanski, K., Araguas-Araguas, L., \& Gonfiantini, R. (1992). Relation between long-term trends of oxygen-18 isotope composition of precipitation and climate. Science, 258, 981-985.

Sodemann, H., Schwierz, C., \& Wernli, H. (2008). Interannual variability of Greenland winter precipitation sources: Lagrangian moisture diagnostic and North Atlantic Oscillationinfluence. Journal of Geophysical Research: Atmospheres, 113 .

Sodemann, H., \& Zubler, E. (2010). Seasonal and inter-annual variability of the moisture sources for alpine precipitation during 1995-2002. International Journal of Climatology: A Journal of the Royal Meteorological Society, 30, 947-961.

845 Stein, A., Draxler, R. R., Rolph, G. D., Stunder, B. J., Cohen, M., \& Ngan, F. (2015). NOAA's HYSPLIT atmospheric transport and dispersion modeling system. Bulletin of the American Meteorological Society, 96, 2059-2077.

Su, L., Yuan, Z., Fung, J. C., \& Lau, A. K. (2015). A comparison of HYSPLIT backward trajectories generated from two GDAS datasets. Science of the Total Environment, 506, 527-537.

Tyler, J. J., Jones, M., Arrowsmith, C., Allott, T., \& Leng, M. J. (2016). Spatial patterns in the oxygen isotope composition of daily rainfall in the british isles. Climate Dynamics, 47, 1971-1987.

Wang, S., Zhang, M., Crawford, J., Hughes, C. E., Du, M., \& Liu, X. (2017). The effect of moisture source and synoptic conditions on precipitation isotopes in arid central asia. Journal of Geophysical Research: Atmospheres, 122, 26672682.

Winschall, A., Sodemann, H., Pfahl, S., \& Wernli, H. (2014). How important is intensified evaporation for Mediterranean precipitation extremes? Journal of Geophysical Research: Atmospheres, 119, 5240-5256. 
Yu, W., Wei, F., Ma, Y., Liu, W., Zhang, Y., Luo, L., Tian, L., Xu, B., \& $\mathrm{Qu}, \mathrm{D}$. (2016). Stable isotope variations in precipitation over Deqin on the southeastern margin of the Tibetan Plateau during different seasons related to various meteorological factors and moisture sources. Atmospheric Research, $170,123-130$.

Yuan, F., \& Miyamoto, S. (2008). Characteristics of oxygen-18 and deuterium composition in waters from the Pecos River in American southwest. Chemical Geology, 255, 220-230. 
Table 1: Summary statistics of $\delta D$ and $\delta^{18} O$ and d-excess of weekly rainfall sampled in the Vallcebre catchments during the period 2011-2013 and 2015-2016 ( $\mathrm{n}=125)$.

\begin{tabular}{lrrr}
\hline Variable & $\delta D(\%)$ & $\delta^{18} O(\%)$ & d-excess $(\% 0)$ \\
\hline Minimum & -152.2 & -19.1 & -4.0 \\
Maximum & 4.4 & -0.8 & 29.4 \\
Mean & -44.1 & -7.2 & 13.2 \\
St. dev. & 25.7 & 3.2 & 5.8 \\
\hline
\end{tabular}


Table 2: Rainfall and isotopic characteristics from the 15 events selected. $\mathrm{t}=$ duration (hours), $\mathrm{R}=$ rainfall depth $(\mathrm{mm}), \mathrm{TP}=$ type of precipitation ( $\mathrm{S}$ : stratiform non-frontal convection, $\mathrm{CF}$ : caused by a cold front, WF: caused by a warm front, L: caused by a low), C = continuity of precipitation along the event, $\mathrm{n}=$ number of samples for the isotopic data, $\bar{x}=$ mean value, $s d=$ standard deviation and IT $=$ observed isotopic trend (V-shaped, Constant, L-shaped).

\begin{tabular}{|c|c|c|c|c|c|c|c|c|c|c|}
\hline \multirow[b]{3}{*}{ Event } & \multirow{2}{*}{\multicolumn{5}{|c|}{ Rainfall characteristics }} & \multicolumn{5}{|c|}{ Isotopic characteristics } \\
\hline & & & & & & & $\delta^{18} O(\%)$ & $\delta D(\%)$ & d-excess $(\%)$ & \\
\hline & Start date (UTC) & $\mathrm{t}(\mathrm{h})$ & $\mathrm{R}(\mathrm{mm})$ & $\mathrm{TP}$ & $\mathrm{C}$ & $\mathrm{n}$ & $\bar{x} \pm s d$ & $\bar{x} \pm s d$ & $\bar{x} \pm s d$ & IT \\
\hline 1 & $26 / 07 / 111700$ & 5.9 & 36.2 & $\mathrm{~S}$ & Yes & 8 & $-8.1 \pm 2.4$ & $-52.4 \pm 19.8$ & $11.1 \pm 0.9$ & $\mathrm{~V}$ \\
\hline 2 & $30 / 07 / 111250$ & 2.5 & 35.8 & $\mathrm{~S}$ & No & 5 & $-5.7 \pm 0.5$ & $-27.2 \pm 2.8$ & $18.7 \pm 2.5$ & ct \\
\hline 3 & 14/11/11 1940 & 30.4 & 29.4 & $\mathrm{CF} / \mathrm{WF}$ & No & 7 & $-7.6 \pm 3.8$ & $-38.8 \pm 33.9$ & $22.3 \pm 6.9$ & $\mathrm{~V}$ \\
\hline 4 & $20 / 03 / 122325$ & 42.0 & 72.8 & WF & No & 11 & $-7.6 \pm 1.9$ & $-40.9 \pm 15.0$ & $20.2 \pm 1.3$ & $\mathrm{~V}$ \\
\hline 5 & 28/04/12 0240 & 22.0 & 34.6 & $\mathrm{CF}$ & No & 7 & $-3.6 \pm 2.9$ & $-17.8 \pm 27.5$ & $10.6 \pm 4.9$ & $\mathrm{~L}$ \\
\hline 6 & $30 / 04 / 120240$ & 9.8 & 28.6 & $\mathrm{~L}$ & Yes & 7 & $-10.8 \pm 1.4$ & $-71.4 \pm 9.9$ & $15.1 \pm 6.1$ & V \\
\hline 7 & $28 / 05 / 121130$ & 6.3 & 16.4 & $\mathrm{~S}$ & No & 5 & $-3.8 \pm 2.8$ & $-19.6 \pm 16.4$ & $10.6 \pm 6.8$ & V \\
\hline 8 & 29/05/12 1130 & 8.8 & 29.8 & $\mathrm{~S}$ & Yes & 6 & $-6.3 \pm 2.2$ & $-38.4 \pm 11.5$ & $12.0 \pm 7.8$ & V \\
\hline 9 & $19 / 01 / 130715$ & 15.6 & 37.8 & $\mathrm{CF}$ & Yes & 8 & $-9.3 \pm 2.0$ & $-62.9 \pm 17.5$ & $11.0 \pm 2.2$ & $\mathrm{~L}$ \\
\hline 10 & 04/03/132020 & 11.8 & 59.8 & WF & No & 13 & $-8.8 \pm 3.1$ & $-58.7 \pm 23.0$ & $11.9 \pm 4.2$ & V \\
\hline 11 & $25 / 04 / 130230$ & 148.2 & 96.4 & $\mathrm{CF} / \mathrm{WF}$ & No & 22 & $-7.4 \pm 4.0$ & $-40.4 \pm 35.9$ & $18.8 \pm 5.3$ & $\mathrm{~V}$ \\
\hline 12 & 20/07/13 1630 & 2.6 & 24.8 & $\mathrm{~S}$ & Yes & 6 & $-4.0 \pm 1.9$ & $-12.9 \pm 12.3$ & $18.9 \pm 3.2$ & V \\
\hline 13 & $23 / 07 / 131605$ & 3.3 & 75.8 & S & Yes & 13 & $-5.3 \pm 2.3$ & $-22.4 \pm 16.0$ & $20.2 \pm 4.3$ & V \\
\hline 14 & $20 / 07 / 151240$ & 5.3 & 19.8 & $\mathrm{~S}$ & Yes & 4 & $-3.0 \pm 0.8$ & $-13.1 \pm 2.93$ & $10.5 \pm 4.3$ & $\mathrm{~V}$ \\
\hline 15 & $22 / 07 / 151705$ & 3.2 & 54.6 & $\mathrm{~S}$ & Yes & 9 & $-9.1 \pm 1.4$ & $-61.0 \pm 11.0$ & $12.1 \pm 3.9$ & V \\
\hline
\end{tabular}


Table 3: Weighted contribution of each region to the final moisture above Vallcebre with valid backward trajectories and d-excess mean value for the 15 events selected. WM=Western Mediterranean, ATL=Atlantic, $\mathrm{POL}=$ Polar, $\mathrm{EUR}=$ Continental Europe and $\mathrm{AFR}=\mathrm{Africa} .0$ indicates a contribution between $0 \%$ and $0.5 \%$ and - a null contribution.

\begin{tabular}{rrrrrrr} 
Event & \multicolumn{7}{c}{ Origin (\%) } & d-excess (\%o) \\
& WM & ATL & POL & EUR & AFR & \\
\hline 1 & 38 & 29 & 2 & - & - & 11.1 \\
2 & 36 & 9 & - & 29 & - & 18.7 \\
3 & 61 & 0 & 0 & 0 & - & 22.3 \\
4 & 23 & 2 & - & 0 & 16 & 20.2 \\
6 & 30 & 39 & - & - & - & 15.1 \\
7 & 56 & 5 & - & - & - & 10.6 \\
9 & 15 & 59 & - & 0 & - & 11.0 \\
10 & 22 & 13 & - & 1 & 6 & 11.9 \\
11 & 30 & 3 & - & 1 & 15 & 18.8 \\
15 & 55 & 29 & - & - & - & 12.1 \\
\hline
\end{tabular}


Table 4: Contributions to the moisture present above Vallcebre for the different instants considered for the three Events selected (2, 9 and 15) (Figure 6a, 7p and 8p) and Event 1 commented in Section 3.4 Hour is the instant chosen to evaluate d-excess changes. The origin is expressed as percentage contribution of each region. WM=Western Mediterranean, $\mathrm{ATL}=$ Atlantic, $\mathrm{POL}=$ Polar, $\mathrm{EUR}=$ Continental Europe and $\mathrm{AFR}=$ Africa. The row tagged as Total indicates the weighted contribution of each region to the final moisture above Vallcebre. - indicates_a null contribution.

\begin{tabular}{|c|c|c|c|c|c|c|}
\hline \multicolumn{7}{|c|}{ Moisture Source Region (\%) } \\
\hline Event & Hour (UTC) & WM & ATL & POL & EUR & AFR \\
\hline \multirow{3}{*}{1} & 18 & 30 & 29 & - & - & - \\
\hline & 20 & 35 & 31 & 4 & - & - \\
\hline & 22 & 48 & 26 & 2 & - & - \\
\hline Total & & 38 & 29 & 2 & - & - \\
\hline \multirow{2}{*}{2} & 13 & 37 & 8 & - & 24 & - \\
\hline & 15 & 33 & 10 & - & 46 & - \\
\hline \multirow[t]{2}{*}{ Total } & & 35 & 9 & - & 29 & - \\
\hline & 09 & 7 & 69 & - & - & - \\
\hline \multirow[t]{2}{*}{9} & 16 & 14 & 57 & - & - & - \\
\hline & 21 & 30 & 51 & - & - & - \\
\hline \multirow[t]{2}{*}{ Total } & & 15 & 59 & - & - & - \\
\hline & 17 & 57 & 30 & - & - & - \\
\hline \multirow[t]{2}{*}{15} & 18 & 42 & 35 & - & - & - \\
\hline & 20 & 65 & 21 & - & - & - \\
\hline Total & & 55 & 29 & - & - & - \\
\hline
\end{tabular}



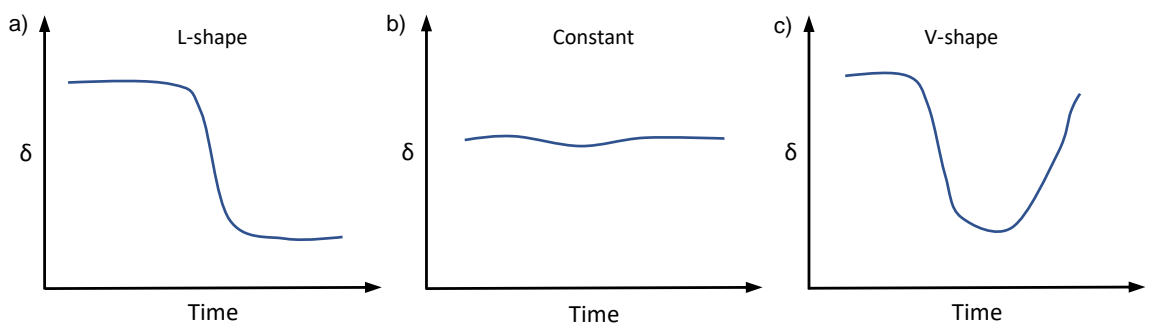

Figure 1: Diagram representing three of the most common isotopic $(\delta)$ trends along time: L-shape (a), constant (b) and V-shape (c) [based on Muller et al. (2015)]. 


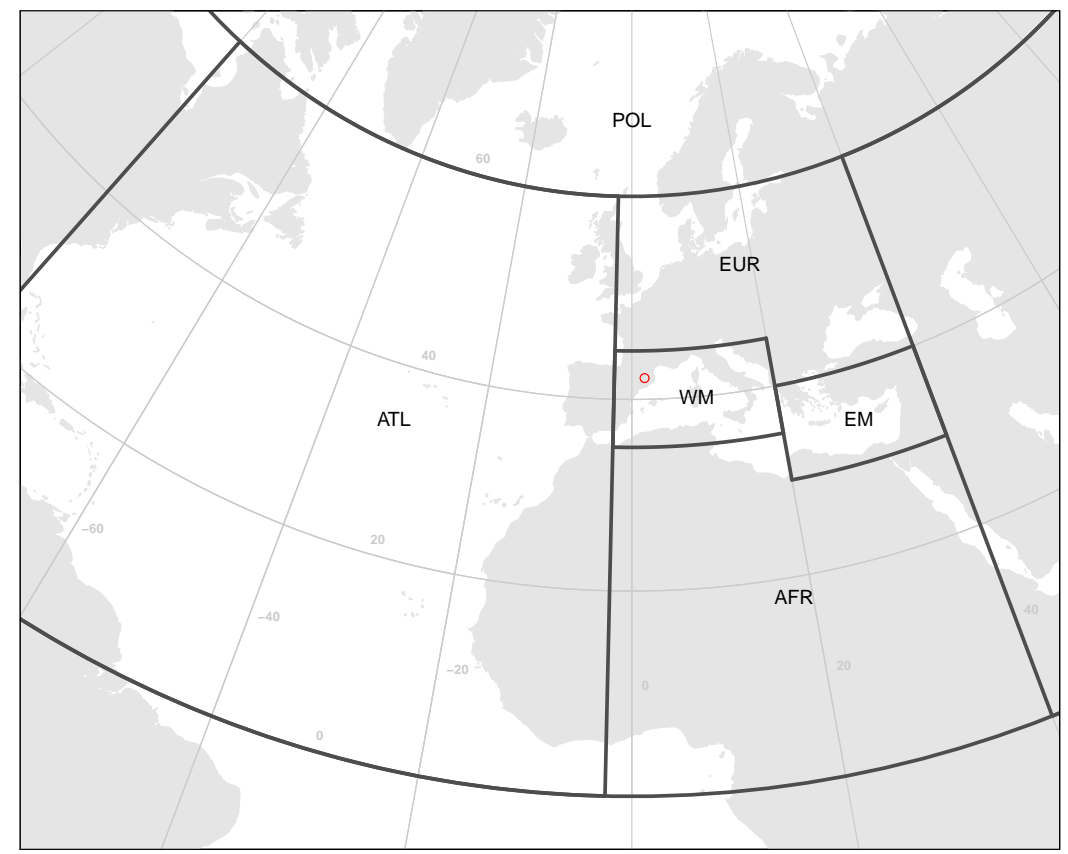

Figure 2: Map of the regions defined to locate the moisture attributions that corresponded to an uptake below the boundary layer. POL for Polar region, ATL for Atlantic, EUR for Continental Europe, WM for Western Mediterranean, EM for Eastern Mediterranean and AFR for Africa. The red dot indicates the Vallcebre Research Catchment area of study. 


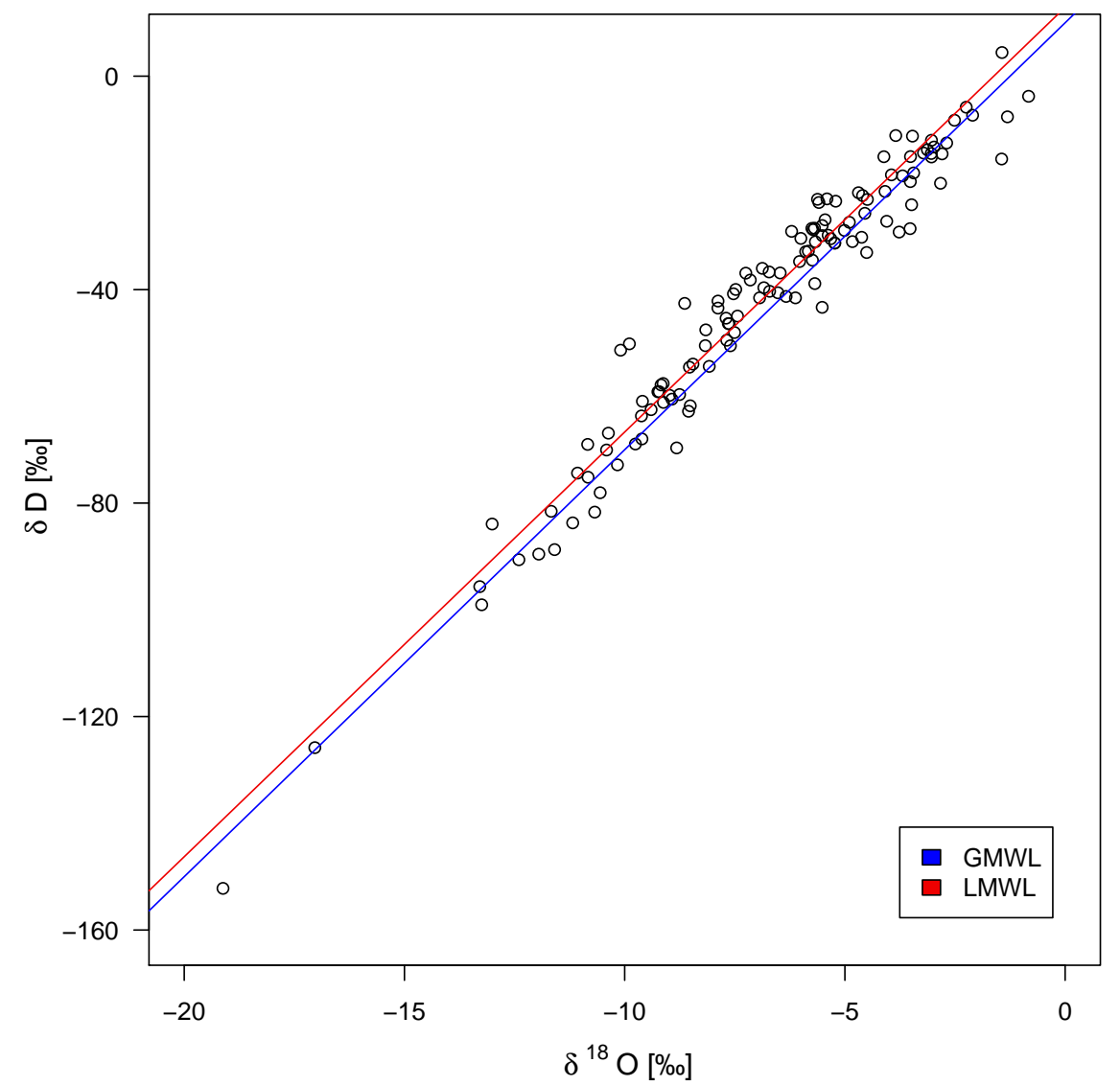

Figure 3: $\delta D$ versus $\delta^{18} O$ plot of weekly rainfall samples $(\mathrm{n}=125)$ collected at the Vallcebre catchments. Lines correspond to the Global Meteoric Water Line (GMWL) (blue) and Local Meteoric Water Line (LMWL) (red). 

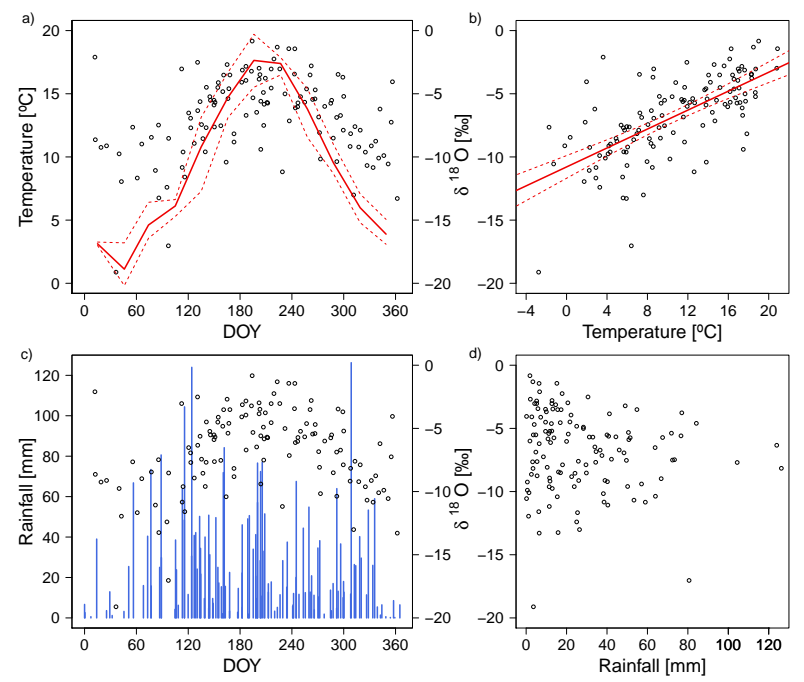

Figure 4: a) Intra-annual variability of $\delta^{18} \mathrm{O}$ precipitation signature (weekly samples) along with monthly mean, minimum and maximum air temperature and c) weekly rainfall amount. b) scatterplot between $\delta^{18} \mathrm{O}$ precipitation signature (weekly samples) and mean weekly air temperature $\left(\mathrm{y}=0.37 \mathrm{x}-10.79, \mathrm{R}^{2}=0.44, \mathrm{n}=125\right)$. d) scatterplot between $\delta^{18} O$ signature in rainfall (weekly samples) and weekly rainfall amount (no significant relationship observed). DOY=Day of year. 


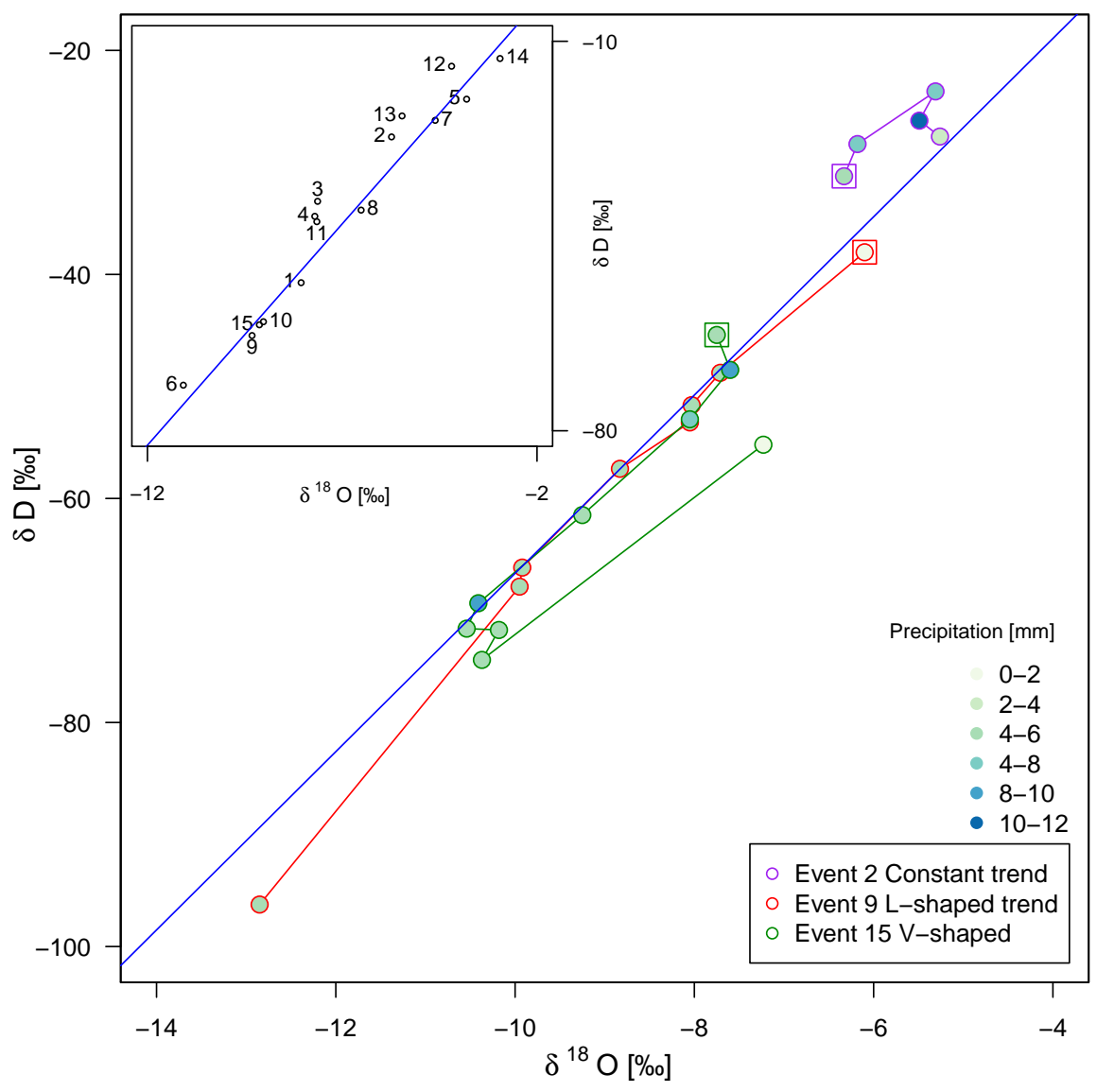

Figure 5: $\delta D$ versus $\delta^{18} O$ at the intra-event scale for three events with different isotopic trends and its correspondent precipitation accumulation. The blue line corresponds to the Local Meteoric Water Line (LMWL). In red, the L-shaped trend (Event 9); in green, the V-shaped (Event 15); and in purple, the constant trend (Event 2). Squares indicate the first sample of the event. The embedded plot shows mean $\delta D$ versus $\delta^{18} O$ for the 15 events selected. 

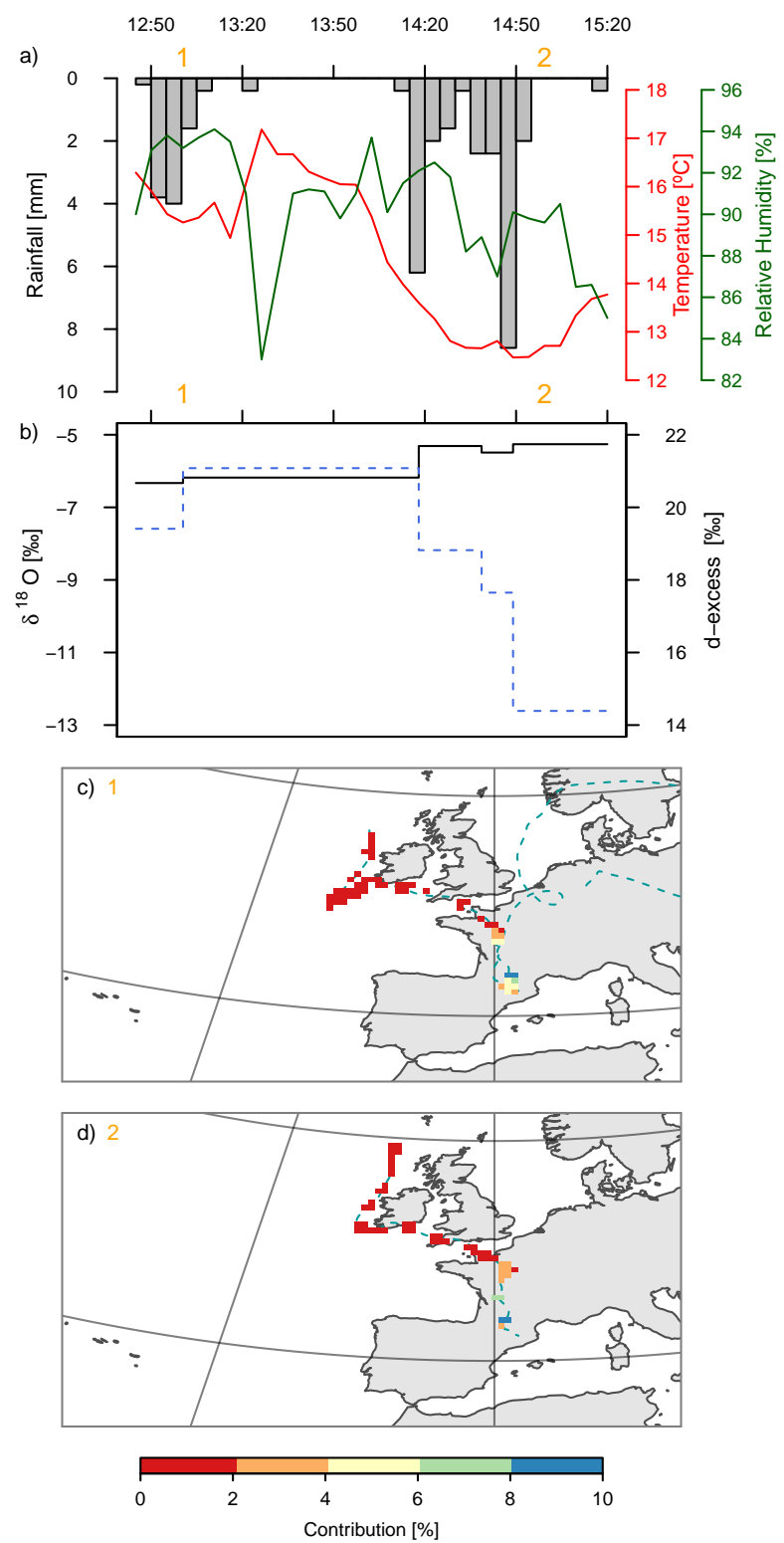

Figure 6: Rainfall amount, air temperature and relative humidity (a), $\delta^{18} O$ (black line) and dexcess (dashed blue line) (b) temporal evolution (in UTC time) for Event 2 (Constant trend). Backward trajectories calculated with the HYSPLIT model and, in blue, moisture cells that contribute to the final humidity above Vallcebre for each instant selected of Event 2 (c, d). 

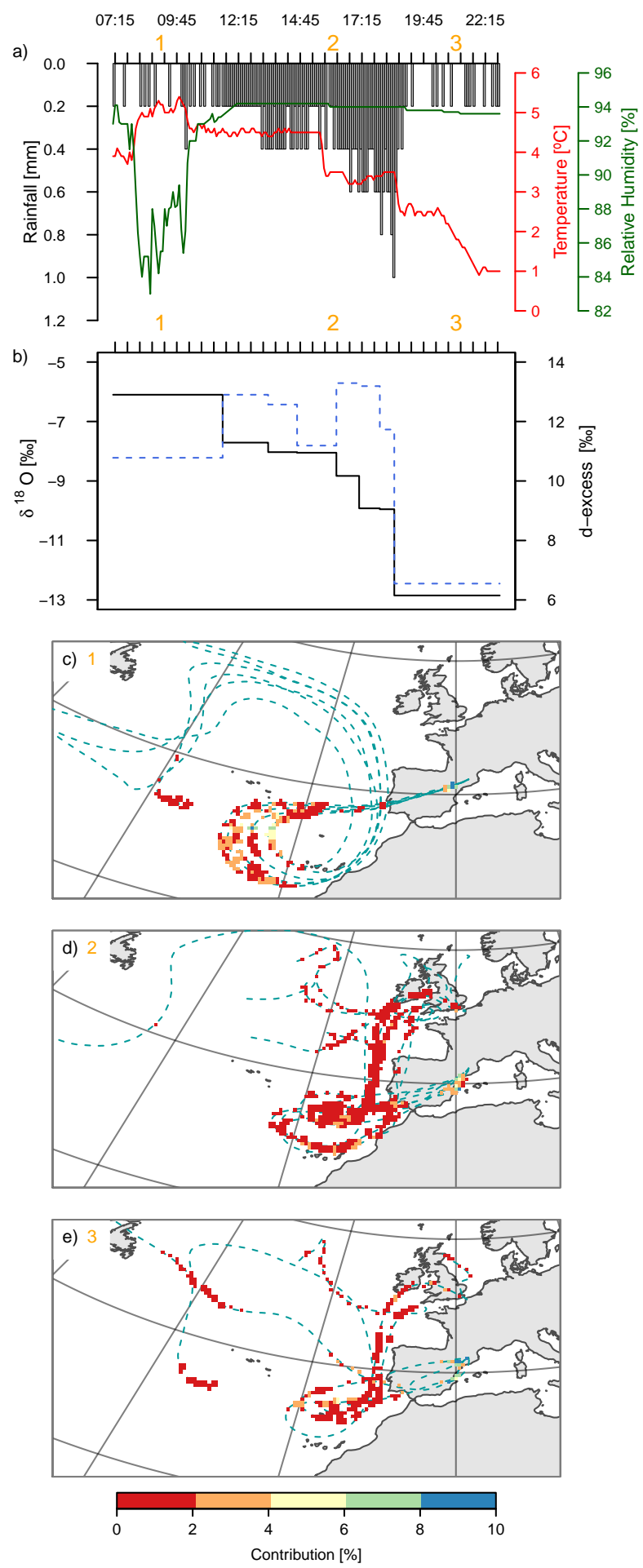

43

Figure 7: Rainfall amount, air temperature and relative humidity (a), $\delta^{18} O$ (black line) and d-excess (dashed blue line) (b) temporal evolution (in UTC time) for Event 9 (L-shape trend). Backward trajectories calculated with the HYSPLIT model and, in blue, moisture cells that contribute to the final humidity above Vallcebre for each instant selected of Event 9 (c, d, e). 

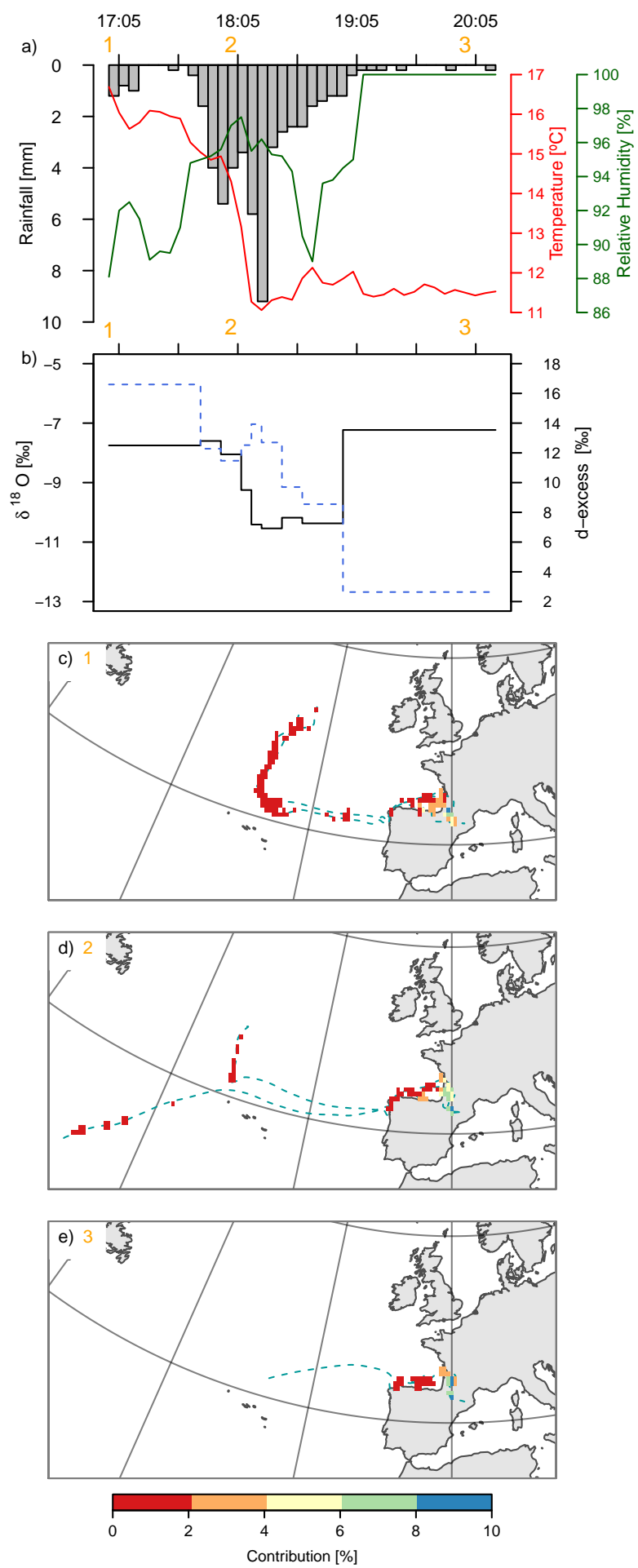

44

Figure 8: Rainfall amount, air temperature and relative humidity (a), $\delta^{18} O$ (black line) and d-excess (dashed blue line) (b) temporal evolution (in UTC time) for Event 15 (V-shape trend). Backward trajectories calculated with HYSPLIT model and, in blue, moisture cells that contribute to the final humidity above Vallcebre for each instant selected of Event 15 (c, d, e). 

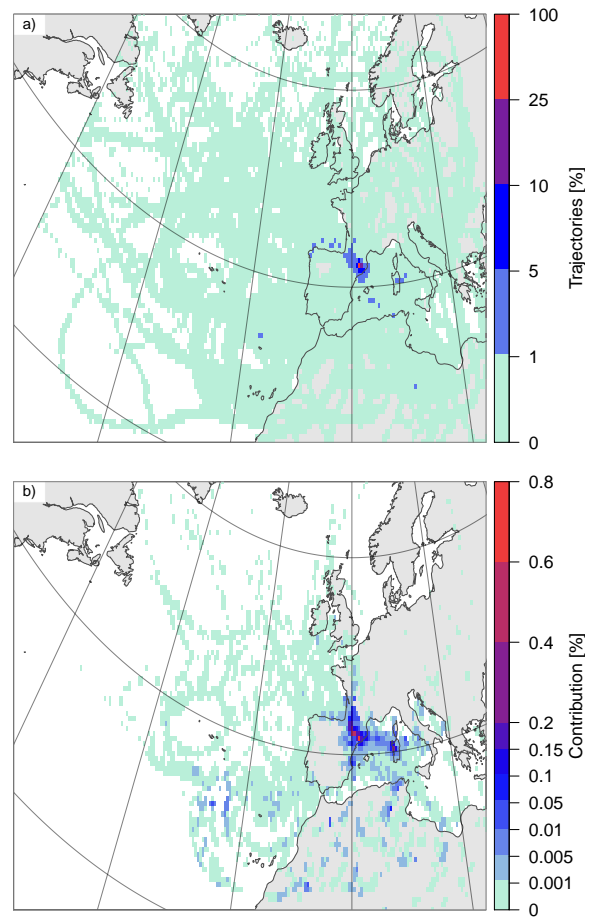

Figure 9: Frequency plot of the ten-day backward trajectories $(n=113)$ ending at Vallcebre Research Catchments obtained with the HYSPLIT model for the 15 events selected (a). Contribution of each cell $\left(0.5^{\circ} \times 0.5^{\circ}\right)$ of the defined grid to the final moisture present above the Vallcebre Research Catchments for the 113 ten-day backward trajectories considered. The colour legend is not uniform in order to highlight the differences between the $0 \%$ and $0.2 \%$ contributions from the cells defined (b). 


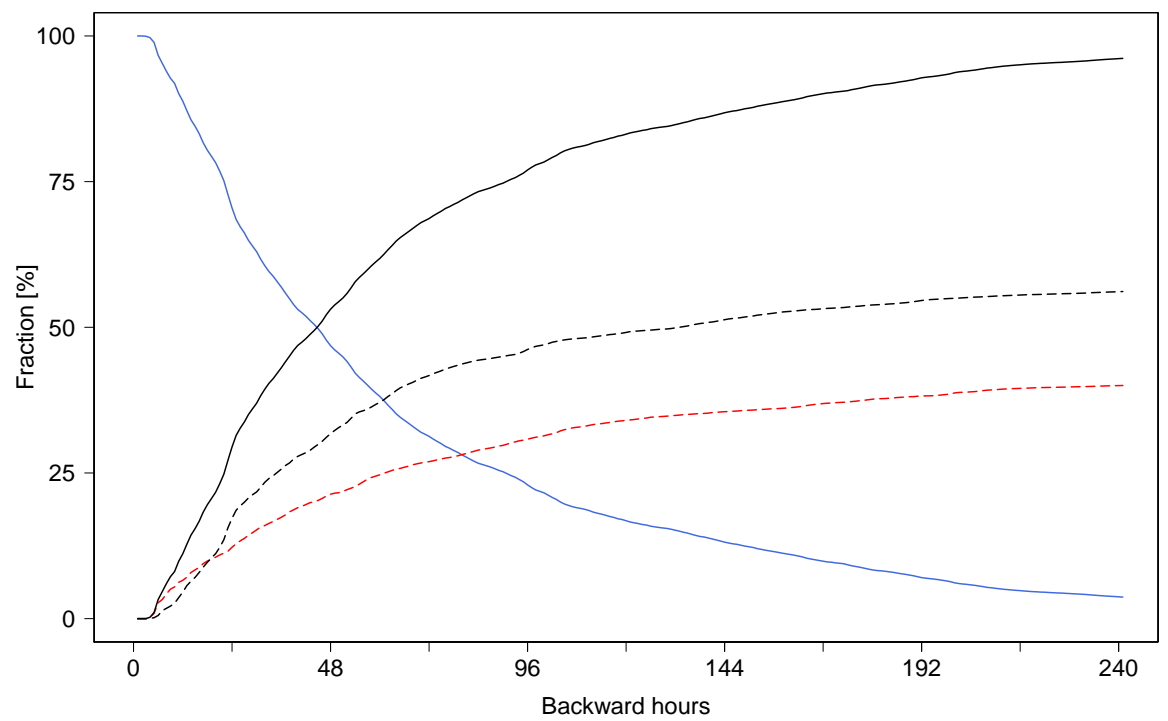

Figure 10: Mean evolution of the known (solid black line), unknown (solid blue line), attributed (dashed black line) and above (dashed red line) tagged moisture for the 113 backward trajectories considered. The backward hours represent the simulation hours of the HYSPLIT model calculations. 


\section{Appendix A. Sensitivity analysis of $\Delta q(t)$}

870 experienced by the moisture sources with different threshold values. As in Wang et al. (2017) a specific humidity range from $0.1 \mathrm{~g} \cdot \mathrm{kg}^{-1}$ to $0.4 \mathrm{~g} \cdot \mathrm{kg}^{-1} \mathrm{using}$ a $0.1 \mathrm{~g} \cdot \mathrm{kg}^{-1}$ step was considered. The results obtained show a reduction of moisture sources identification as the threshold increased (Table A.1), which is in accordance with Sodemann et al. (2008). In addition, Table A.1 includes the percentages of moisture that could be identified for the most important moisture source regions (Figure 2). It shows a progressive increase of moisture contribution for the Western Mediterranean area, a decrease for the Atlantic Basin and a fluctuation for the African source region. Total moisture attribution differences due to considering $0.1 \mathrm{~g} \cdot \mathrm{kg}^{-1}$ instead of $0.2 \mathrm{~g} \cdot \mathrm{kg}^{-1}$ are below $8 \%$, which is negligible for the purpose of this study.

Furthermore, as uptakes in Sodemann et al. (2008) were at 6 hours time resolution and in this study they were reduced to 1 hour, HYSPLIT's output specific humidity value changes $(\Delta q(t))$ dependence on time resolution was also analysed. The goal of this analysis was to determine the occurrence and subsequent contribution of $0.1 \mathrm{~g} \cdot \mathrm{kg}^{-1} \Delta q(t)$ values at both indicated time resolutions compared to all possible moisture uptakes. From all the trajectories calculated, either considered valid or not (Section 2.5), all potential uptakes (positive $\Delta q(T)$ values) were analysed. The results obtained show that for 1 hour time resolution uptake occurrences of $0.1 \mathrm{~g} \cdot \mathrm{kg}^{-1}$ represented $49 \%$ of the potential uptakes, whereas in case of 6 hours this percentage was reduced to 17\%. In terms of total potential moisture uptakes 1 hour resolution $\Delta q(t)$ of $0.1 \mathrm{~g} \cdot \mathrm{kg}^{-1}$ represented $19 \%$ and it only represented $2 \%$ for 6 hours time resolution. For all the above reasons, a $\Delta q(t)$ value of $0.1 \mathrm{~g} \cdot \mathrm{kg}^{-1}$ was considered suitable. 
Table A.1: Results of moisture sources identification considering different $\Delta q(t)$ uptake values. Attributed column accounts for the percentage of the total moisture sources identified. The last three columns represent the attributed value itemized for three of the defined regions: Western Mediterranean (WM), Atlantic Basin (ATL) and Africa (AFR).

\begin{tabular}{lrrrr}
\hline$\Delta q(t)$ threshold $\left(\mathrm{g} \cdot \mathrm{kg}^{-1}\right)$ & Attributed $(\%)$ & WM $(\%)$ & ATL $(\%)$ & AFR (\%) \\
\hline 0.1 & 56 & 58 & 25 & 14 \\
0.2 & 49 & 62 & 21 & 14 \\
0.3 & 40 & 67 & 15 & 11 \\
0.4 & 28 & 75 & 7 & 15 \\
\hline
\end{tabular}

